TOUCHED BODIES 



\section{TOUCHED BODIES}

The Performative Turn in Latin American Art

MARA POLGOVSKY EZCURRA

\section{iri}

RUTGERS UNIVERSITY PRESS

New Brunswick, Camden, and Newark, New Jersey, and London 
Library of Congress Cataloging-in-Publication Data

Names: Polgovsky Ezcurra, Mara, author.

Title: Touched bodies : the performative turn in Latin American art / Mara Polgovsky Ezcurra.

Description: New Brunswick, New Jersey : Rutgers University Press, [2019] | Includes bibliographical references and index.

Identifiers: LCCN 2018057616 | ISBN 9781978802025 (pbk. : alk. paper) | ISBN 9781978802032 (cloth : alk. paper)

Subjects: LCSH: Performance art-Latin America. | Body art-Latin America. | Arts, Latin American — 2oth century. | Arts and society—Latin America—History2oth century. | Arts-Political aspects-Latin America-History-2oth century.

Classification: LCC NX456.5.P38 P65 2019 | DDC 709.04/0752—dc23

LC record available at https://lccn.loc.gov/2018057616

A British Cataloging-in-Publication record for this book is available from the British Library.

Copyright (C) 2019 by Mara Polgovsky Ezcurra

All rights reserved

No part of this book may be reproduced or utilized in any form or by any means, electronic or mechanical, or by any information storage and retrieval system, without written permission from the publisher. Please contact Rutgers University Press, 106 Somerset Street, New Brunswick, NJ 08901. The only exception to this prohibition is "fair use" as defined by U.S. copyright law.

๑) The paper used in this publication meets the requirements of the American National Standard for Information Sciences-Permanence of Paper for Printed Library Materials, ANSI Z39.48-1992.

www.rutgersuniversitypress.org

Manufactured in the United States of America 
To Demetrio and Eugenio, lovingly 
